\title{
The Role of Arthroscopy in Mini-Invasive Treatment of Tibial Plateau Fractures
}

\author{
Şt. Cristea, A. Prundeanu, \\ Fl. Groseanu and D. Gârtonea \\ Clinic of Orthopaedic and Trauma Surgery, \\ St. Pantelimon Hospital \\ Romania
}

\section{Introduction}

The treatment of tibial plateau fractures represents a challenge in current activity of an orthopedic surgeon, because these kind of fractures have an intraarticular trajectory. It is important in this kind of fractures to have a good mobility after treatment (Mills \& Nork SE, 2002). Instead of the standard treatment with one or two plates and screws, one should try to use the reduction of the fracture's fragment with Kirschner wires under Rx control and fix the fragments with K wires, screws and external fixation (Marsh et al., 1995; Morandi \& Pearse, 1996). Open reduction and internal fixation has a significant complication rate and this has encouraged interest in percutaneous techniques, most of which associate arthroscopy and fluoroscopy. Arthroscopy is useful to provide a good view of the articular surface and allows assessment of associated intra-articular lesions.

The objectives of this treatment are to obtain a good articular congruity, axial alignment, joint stability and functional motion.

\section{Method}

Minim invasive treatment and arthroscopic postreduction control are performed based on the Schatzker's classification, (Buchko \& Johnson, 1996; Cristea et al., 2010; Kenneth A.E.\& Kenneth J. K., 2006).

\section{Diagnostic}

The clinical diagnostic is sustained by the following clinical signs:

- $\quad$ swelling of the knee;

- hemarthrosis;

- pain;

- $\quad$ varus or valgus tibial deviation;

- impossible weight bearing;

- $\quad$ restriction for active movements of the knee joint. 

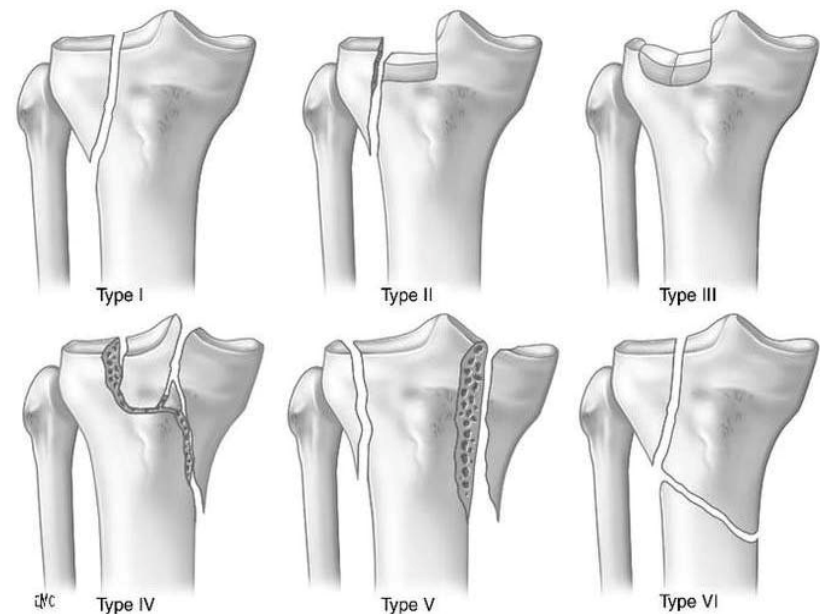

Fig. 1. Schatzker's Classification

\subsection{Radiological diagnostic}

Different kinds of Xray exposures are used :

- antero-posterior;

- lateral;

- $\quad$ oblique internal or external;

- $\quad$ in tension-evaluate the reduction (ligamentotaxis)
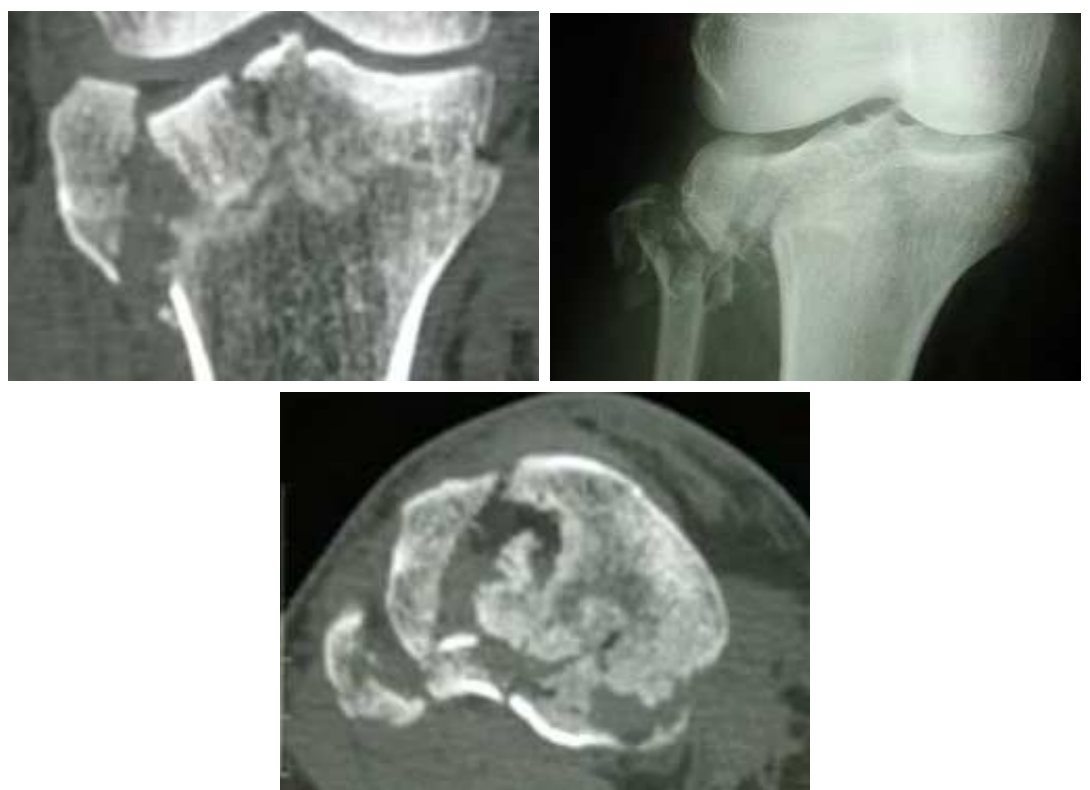

Fig. 2. Schatzker's V - CT and X Ray aspects 


\subsection{CT diagnostic}

Using the reconstruction in sagital and coronal plane of the images more information about the type and localization of the fracture is obtained (Rafii et al., 1987). CT exam is mandatory for the surgical treatment planning in type IV, V and VI Schatzer. By all experience of using $\mathrm{CT}$ and Xray exams, after several different cases, the surgeon will understand the fracture aspect only by Xray exams.

\section{Surgical treatment}

Most surgeons use different kind of plates with screws with open reduction of the fracture:

- "L" plate;

- LC DCP plate;

- two plates;

- plate and external fixation.

The minimal invasive surgical treatment of these kind of fractures should be done under fluoroscopic and arthroscopic control.

This technique is particularly adapted to each Schatzker type, inspite of others (Casteleyn \& Handelberg, 2001) considering a limited role of arthroscopy only in relative simple split, depression and split-depression fracures.

The patient is under spinal anesthesia, then the fragments of the fracture are identified using Xray control. The reduction of the fracture is then atempted by flexion, extension, traction (ligamentotaxis) (Sirkin et al., 2000).

Standard arthroscopic portals can be used, joint irrigation is mandatory with a low pressure gravity feed, and a tourniquet is always necessary to reduce bleeding. Some arthrocopic surgical experience is necessary. The scope must be left for a few seconds in the same position in order to flush the blood and visualise the lessions. Prolonged operation time may lead to increased fluid effusion with compartimental syndrome or deep venous thrombosis.

The technique will be described particularly adapted to each Schatzker type.

In case of fractures with pure cleavage, split fractures, $\mathrm{K}$ wires are inserted rectangularly on the fracture's line, subchondral, under Xray and arthroscopic guidance. Eventually compression forces are applied by putting cannulated cancellous screws in paralel planes.

In case of fractures with depression, a $\mathrm{K}$ wire is inserted in the depressed bone fragment. Then this bone fragment is lifted under Xray and arthroscopic control and then another $\mathrm{K}$ wire is inserted through these reduced bone fragments, subchondral. Eventually compression forces are applied by putting cancellous screws in paralel planes.

In case of combinated fractures, cleavage and depression a $\mathrm{K}$ wire is inserted through the fracture's cleavage directly in the depressed bone fragment, and this depressed bone fragment is lifted using strong forces till the $\mathrm{K}$ wire is bend, under Xray and arthroscopic control. Then another $\mathrm{K}$ wire is inserted through these reduced bone fragments, perpendiculary to the cleavage fracture, then compression forces are applied by putting paralel cancellous screws. After the alignment of the articular surface is obtained these fragments are fixed with cancellous screws or another $\mathrm{K}$ wire. In case of cominuted fractures, first the depression is reduced and then the cleavage. The forces applied on the $\mathrm{K}$ wire for the alignment of the fracture are very strong (Cristea et al., 2010).

In case of Schatzker type V-VI external fixation is used after obtaining the alignment of the articular surface ( Cristea et al., 2010). 
Indirect reduction techniques have the advantage of minimal soft tissue striping and fragment devitalization (Kenneth A.E.\& Kenneth J. K., 2006). For badly comminuted fractures an external fixator is used such as femoral - tibial distractor, eventually articulated. Closed methods are prefered in order to elevate depressed fragments, which can be carried out under fluoroscopic or arthroscopic guidance (Buchko \& Johnson, 1996; Cristea et al., 2010). Bone tamps are placed under image and the depressed segments are elevated. Accuracy of reduction may be checked with the aid of the arthroscope. In type IV-VI because there are significant forces, lag screws alone are not sufficient to stabilize these fractures and external fixation is used.
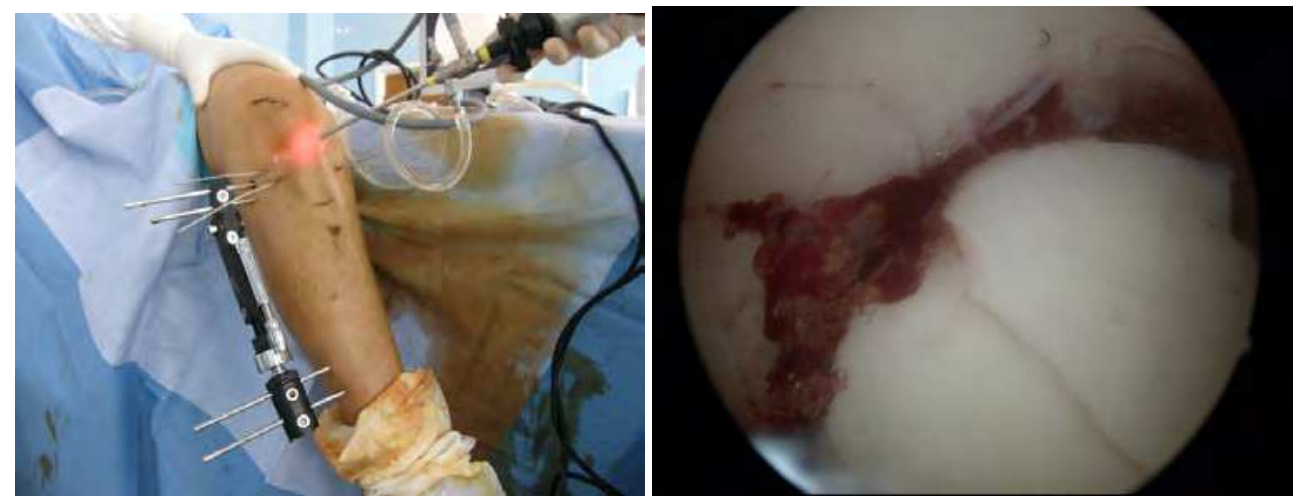

Fig. 3. External fixator and minim invasive reduction under $\mathrm{X}$ ray and arthroscopic control intraoperative aspects
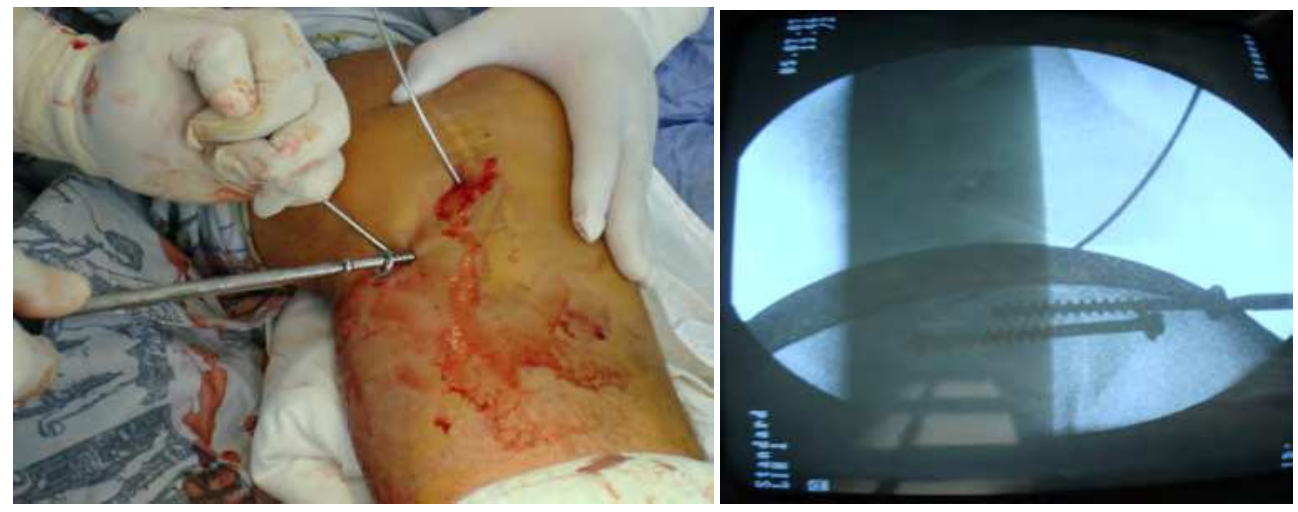

Fig. 4. Minim invasive reduction under $X$ ray and arthroscopic control - intraoperative aspects

\subsection{Asociated meniscal and ligamentous lesions}

Diagnosis and immediate treatment of associated meniscal lesions by partial meniscectomy and debridement can be performed during initial arthroscopy. These may account for a lower incidence of degenerative changes in arthroscopically treated fractures cases. The 
collateral ligaments sprains do not require surgical treatment. They can be futher protected during mobilisation with an articulated cast-brace or a rehabilitation brace when the joint immobilisation is not necessary. The ACL lesions are reevaluated after the fracture healing and late reconstruction could be necessary.

Various lessions of soft tissue are associated with tibial plateau fractures. These are usually neglected by most traumatic surgeons. All the meniscus lessions type, capsular disruption, intraarticular haematomas, osteochondral small fragments, ACL various lessions or collateral ligaments are associated with tibial plateau fractures.

Based on the OR findings, in our opinion, the following classification of soft tissue lessions should be added to each type of Schatzker fractures:

- A1-without lesions of the meniscus or ACL

- A2-with tears of the meniscus - repaired by excision and debridement

- $\quad$ B1-lesions of the meniscus - which must be sutured

- B2-fracture of the tibial plateau spine - which must be repared in emergency

- $\quad$ C1- with desinsertion of ACL from femoral insertion - which should be repared in emergency

- $\quad$ C2-with ireparable rupture of ACL, which can be repared later in another surgical session.
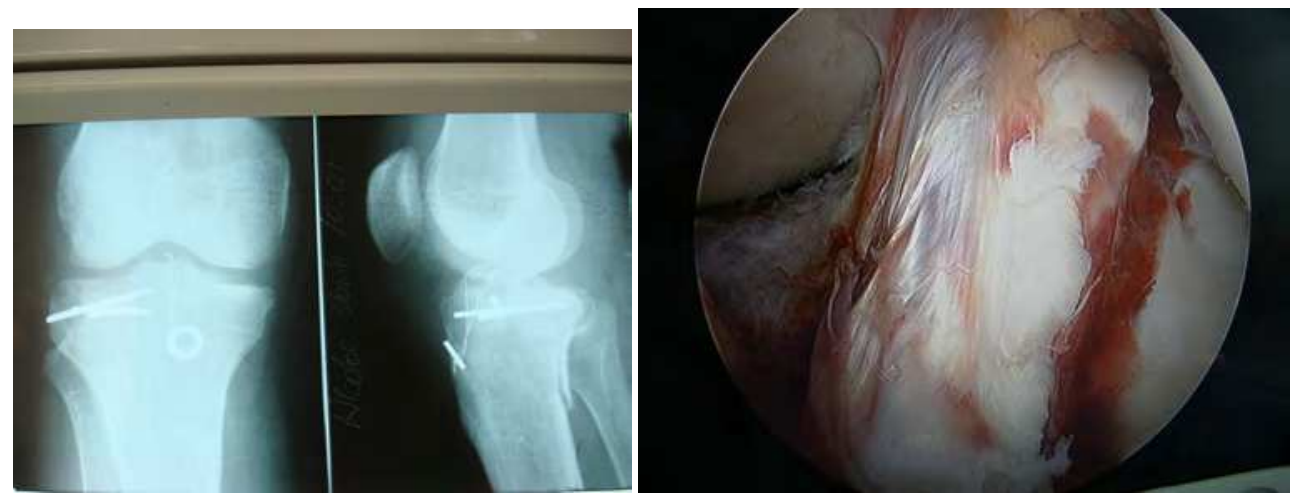

Fig. 5. Minim invasive reduction of complex fracture which includes the spinal plateau. $X$ ray and Arthroscopic control - after reduction

\subsection{Author's experience and statistical analysis}

Between 2006-2010 we had 398 tibial plateau fractures and for 262 we used surgical treatment. Of those $68 \%$ were external plateau fractures; $18 \%$ were internal plateau fractures and $14 \%$ were bilateral plateau fractures. We saw a great discrepancy between radiology and CT. On the Xray and CT we follow and appreciate the deplacement degree, fracture's type and indication of treatment (Tscherne \& Lobenhoffer, 1993).

We obtained very good results in $80 \%$ of cases, but also we have one case with infection after a month which neccessitate extraction of the screws and wires; in $15 \%$ of cases we obtained a mobility of the knee around 95-105 degree of fexion; in $4 \%$ of cases we were not able to restore the entire surface of the tibial plateau. 

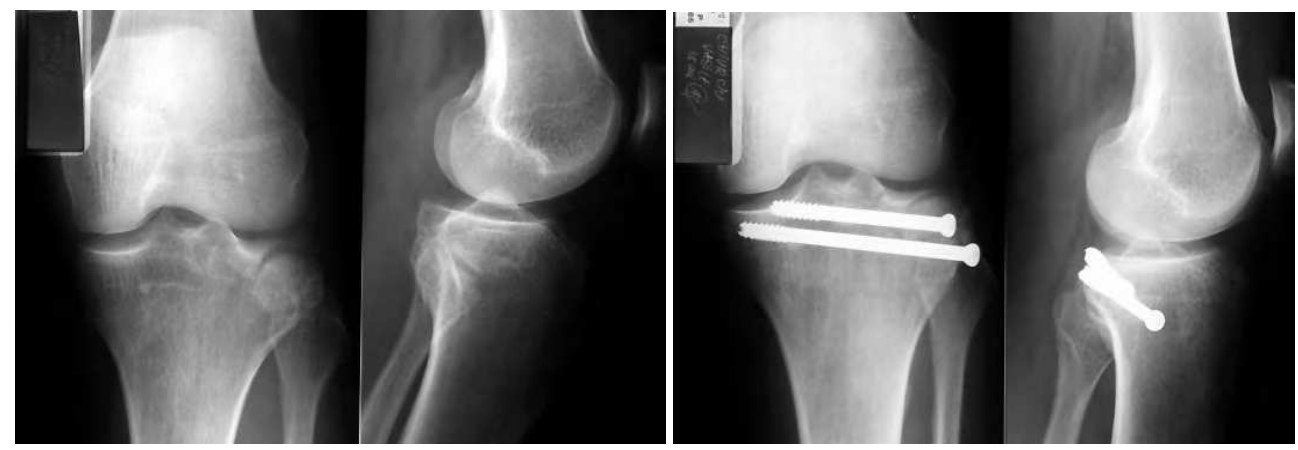

Fig. 6. X ray Pre and postoperative aspects

The statistical analysis was obtained with the use of SASTM computer software, version 9.1.3, Cary U.S. To compare the subgroups on the basis of quantitative variables, a Student test was used. For the qualitative variables, a Pearson's Khi ${ }^{2}$ was used or a Fisher's exact test if the theoretical numbers were too low.. The degree of significance chosen for the overall risk of the first case was fixed at $5 \%$ in both situations.

In our study several international systems of evaluation were used (KOOS scores, IKS, Lysholm, Tegner and Rasmussen) thus permiting a comparison with a larger number of literature series. In general our functional results were satisfying and comparable to other series.

In table 1 and 2 we compare our results with other international studies in literature.

\begin{tabular}{|l|c|c|c|c|c|}
\hline & $\begin{array}{c}\text { Scheerlin } \\
\text { C.K., } 1998\end{array}$ & $\begin{array}{c}\text { Cassard, } \\
1999\end{array}$ & Rossi,2008 & $\begin{array}{c}\text { Siegler, } \\
2009\end{array}$ & $\begin{array}{c}\text { Our } \\
\text { series, } \\
2010\end{array}$ \\
\hline Number of patients & 52 & 44 & 57 & 28 & 262 \\
\hline Number of follow-up patients & 38 & 44 & 46 & 21 & 184 \\
\hline Average age & 47 & 46 & 48 & 43 & 51 \\
\hline Average follow-up (months) & 62 & 69 & 60 & 59,5 & 60 \\
\hline Associated lessions (\%) & 53,8 & - & 39 & 32,1 & 63 \\
\hline Meniscal lesions (\%) & - & - & 28 & 7,1 & 53 \\
\hline ACL Lessions (\%) & - & - & 11 & 3,6 & 10 \\
\hline $\begin{array}{l}\text { Postoperative } \\
\text { complications (\%) }\end{array}$ & 15,4 & - & 3,5 & 0 & 4,9 \\
\hline IKS average & - & 92 & 93,2 & 85,2 & 93 \\
\hline IKS functional average & - & 96 & 94,8 & 91 & 95 \\
\hline Clinical Rasmussen average & - & - & 28,2 & 25,5 & 9 \\
\hline $\begin{array}{l}\text { Radiological Rasmussen } \\
\text { average }\end{array}$ & - & - & - & 25,5 & 9 \\
\hline Arthrosis Xray (\%) & 28,9 & 20 & 8,6 & 47,6 & 25 \\
\hline Malalignment (\%) & 15,8 & - & 8,7 & 32,1 & 4,9 \\
\hline
\end{tabular}

ACL : anterior cruciate ligament ; IKS : International Knee Society.

Table 1. Mean results of tibial plateau fractures. 


\begin{tabular}{|c|c|c|c|c|c|c|c|c|c|c|c|}
\hline 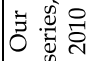 & స్ స్ & n. 8 & 8 in & $3 \circ$ & भे & 2 & ू & ส & $\sigma$ & $a$ & $\stackrel{2}{\sim} \underset{7}{7}$ \\
\hline 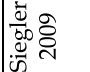 & $\underset{\sim}{\infty}$ & ?. & & $\begin{array}{l}*=0 \\
\infty\end{array}$ & 0 & $\mid \begin{array}{c}2 \\
x^{2} \\
\infty\end{array}$ & $\sigma$ & $\infty$ & 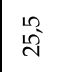 & $\infty$ & 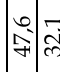 \\
\hline 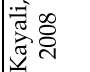 & $\bar{N}=$ & a $\underbrace{\infty}_{\infty}$ & 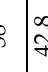 & \begin{tabular}{lll}
0 & 0 \\
\cline { 1 - 1 } & &
\end{tabular} & 0 & 1 & 1 & 1 & 1 & 1 & ন 1 \\
\hline ). & $\div$ & \begin{tabular}{lll}
$\infty$ & 7 \\
\hdashline & 7
\end{tabular} & 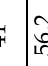 & $\begin{array}{ll} & \\
0 & \\
0\end{array}$ & 0 & 1 & 1 & 1 & $\begin{array}{l}\text { ñ } \\
\text { ลิ }\end{array}$ & 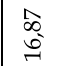 & 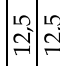 \\
\hline 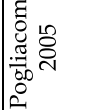 & $\Rightarrow$ & $\stackrel{n}{n} \approx$ & $y$ & $\begin{array}{c}y \\
\text { val }\end{array}$ & 1 & 1 & 1 & 1 & 1 & 1 & 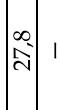 \\
\hline 荽 & कo & की & $\stackrel{9}{2}$ & ه & F & 1 & I & 1 & I & 1 & $\begin{array}{lll}8 & 1\end{array}$ \\
\hline 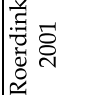 & পিগ & $\begin{array}{l}N \\
\text { n }\end{array}$ & $p q$ & $\begin{array}{l}P \mid l \\
0\end{array}$ & $\ddot{m}^{2}$ & 1 & 1 & 1 & 1 & 1 & $\begin{array}{lll}1 & 1\end{array}$ \\
\hline 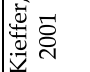 & సे & 난 & $\begin{array}{ll}-4 \\
\cdots\end{array}$ & $\begin{array}{c}0 \\
0 \\
c \\
1\end{array}$ & के & 1 & 1 & 1 & 1 & 1 & సे \\
\hline ज्ञ & นึ) & 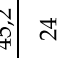 & ते & $\circ \approx$ & 0 & 1 & 1 & 1 & in & 1 & 111 \\
\hline 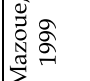 & $\approx \approx$ & \begin{tabular}{l}
0 \\
\multirow{3}{*}{} \\
\multirow{3}{*}{}
\end{tabular} & 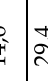 & सै: & $\begin{array}{l}0 \\
\stackrel{0}{*}\end{array}$ & 1 & 1 & 今े & 1 & 1 & |̇ \\
\hline 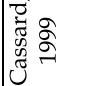 & $\sim 2$ & 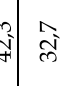 & $\hat{j}$ & 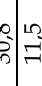 & $\approx$ & Fే & 今 & 1 & 1 & 1 & 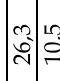 \\
\hline 突 & $\bar{m}=$ & & & $\vec{v} \stackrel{2}{\rightarrow}$ & హु & 1 & I & 1 & 1 & 1 & $\begin{array}{lll} & 1 & 1\end{array}$ \\
\hline & 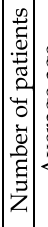 & 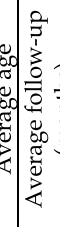 & 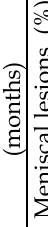 & 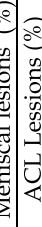 & 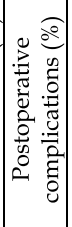 & 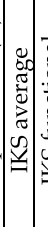 & 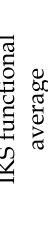 & 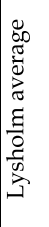 & 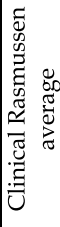 & 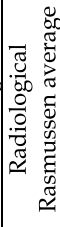 & 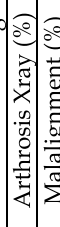 \\
\hline
\end{tabular}

Table 2. Short term results of the tibial plateau fractures 
ACL : anterior cruciate ligament ; IKS : International Knee Society.

We reduced the infection rate by:

- $\quad$ reduced time of surgery;

- $\quad$ minimal dissection;

- $\quad$ extraperiosteal dissection;

- $\quad$ minimal size of implants;

- $\quad$ antibiotics.

We use anticoagulant therapy for thrombembolism profilaxy. There were no DVT or pulmonary embolism (PE) complications in our series. There was no compartmental syndrome in our series due to low pressure during joint irrigation in arthroscopy, no pump was used.

\section{Postoperative care}

\subsection{Deep venous thrombosis (DVT) prevention}

As tibial plateau fractures are associated with considerable soft tissue trauma and sometimes with prolonged operation times using a tourniquet, DVT is not a rare complication (Williams et al., 1995).

The use of one of the low-molecular-weight heparins is advisable. One should prolong their use for more than 3 weeks until the complete mobilisation of the knee and the pacient. Foot and calf mechanical compression devices can also be used with success. Compressive antithromboembolic stockings are always mandatory.

\subsection{Mobilisation}

Once a satisfactory fracture reduction and stabilisation have been obtained, the immediate mobilisation is done. The soft tissue and skin coverage lesions are limited. Immediate continuous passive motion (CPM) can be beneficial for the restoration of the articular homeostasis and the remodelling of the small articular fragments. When the external fixator locks the knee, a stable construct to early mobilisation of the pacient is mandatory. In generaly at 3-6 weeks the articular mobility is achieved, depending of the fracture type and stability of the fixation.
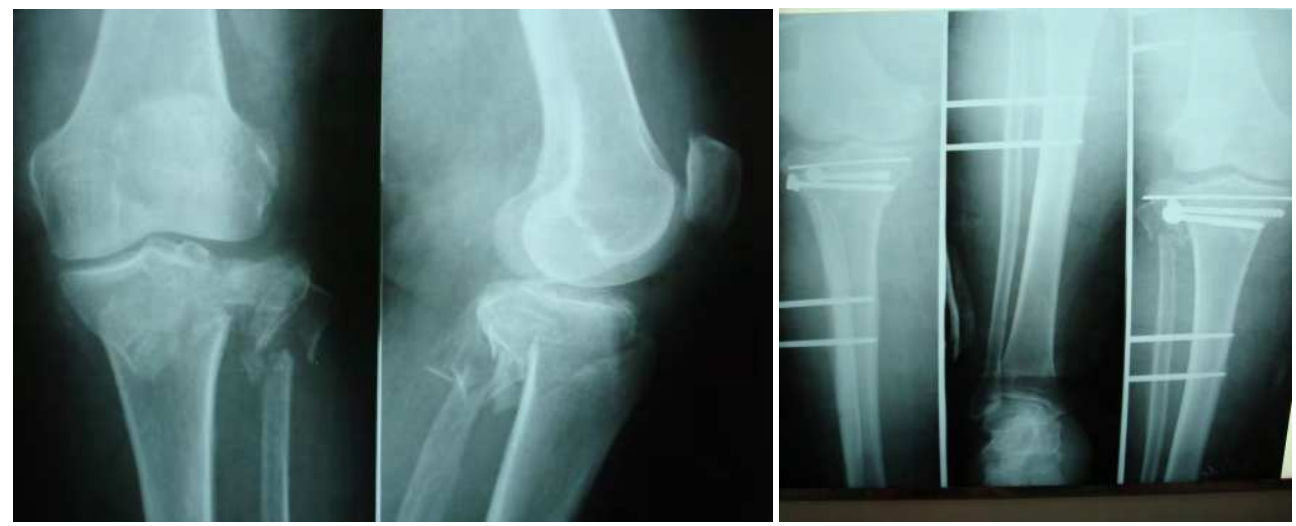

Fig. 7. $\mathrm{X}$ ray Pre and postoperative aspects 

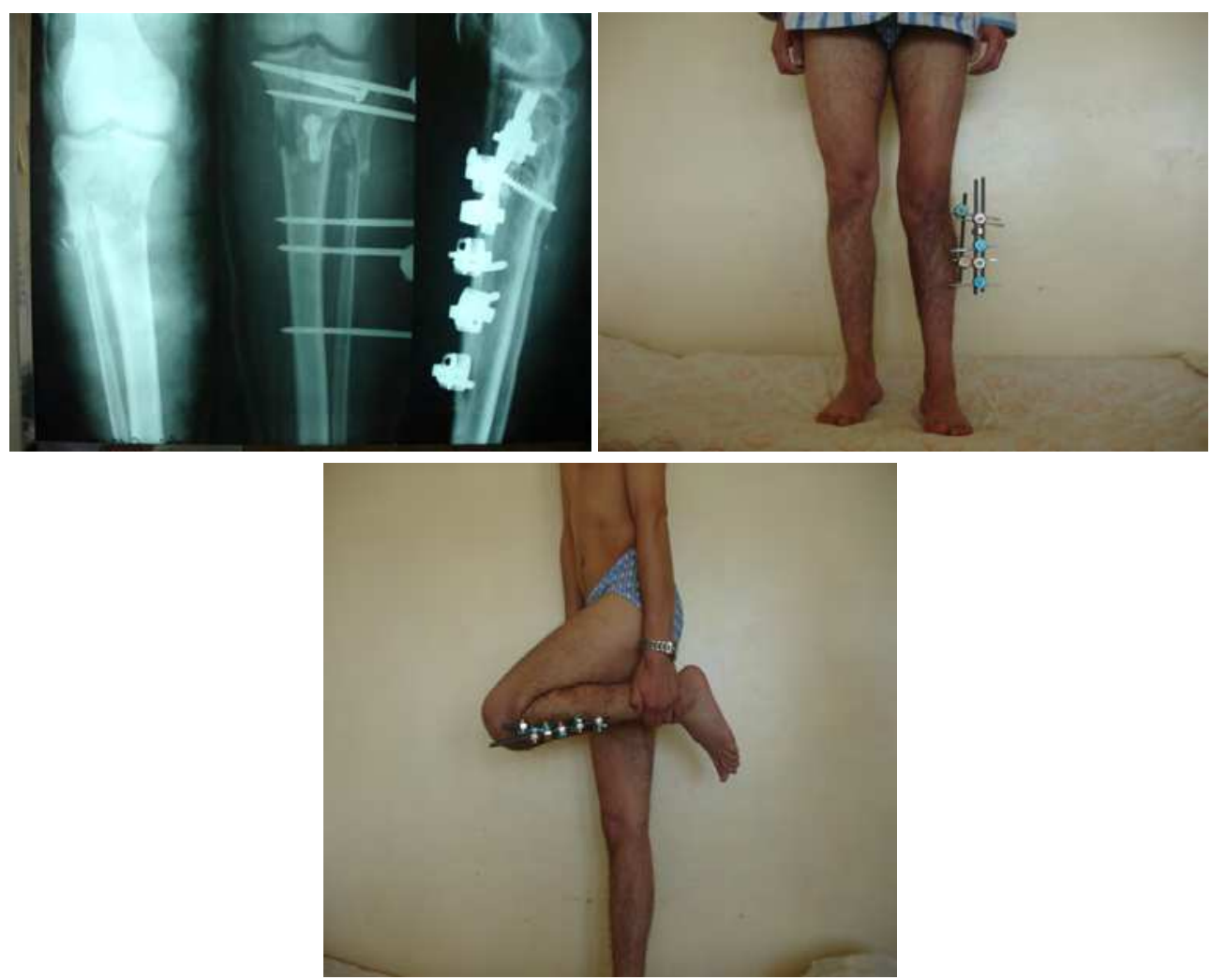

Fig. 8. $\mathrm{X}$ ray Pre and postoperative aspects

\subsection{Weight-bearing}

In general, walking with crutches with minimal load bearing is possible after a few days. In simple fractures, or stable construct fixation full bearing is allowed at 10-12 weeks. The articulated cast braces or rehabilitation braces can be usefull in early rehabilitation. Secondary, progressive impaction of the depressed zone can occur due to weight bearing, even 4 to 5 months postoperatively, especially in obese patients or those with ostheoporotic bone.

\section{Complications}

The risk of infection is reduced due to: shortened time of surgery, minimal dissection, extraperiosteal dissection, minimal size of implants, antibiotics. The implants ablation and antibiotics resolve that rare complication, while in classical open surgery the rate of infections and stiffness is $10 \%$. 
Posttraumatic arthritis in 4a patient with bicondylar fracture could be a good indication for total knee replacement. In only $4 \%$ of cases the restore of the entire surface of the tibial plateau was not achieved. The varum deviation was finally observed in $3 \%$ of patients, with maximum value of $5^{0}$.

\section{Conclusion}

This kind of articular fractures requires perfect alignment of fracture's fragments. It is difficult to treat these fracture especially type $V$ and type VI Schatzker.

Beside the standard treatment with one or two plates and screws, one could use the reduction of the fracture's fragment with $\mathrm{K}$ wire under Xray and arthroscopic control, and then fix the fragments with $\mathrm{K}$ wire and screws. First of all it is important to establish the fracture's type. Schatzker classification is commonly used for their identification. The preoperative planning is necessary and also the X-ray and CT scan. For this technique different kind of material is used: $\mathrm{K}$ wire, screws, external fixation, fluoroscope, and arthroscopy.

The role of arthroscopy in these fractures is twofold: 1 . To confirm the quality of a good reduction, 2. To accurately asses and treat the associated lesions of the soft tissue - menisci, cruciate ligaments, capsular disruption.

This minimal invasive technique is useful for the treatment of this kind of fractures and in most cases has good outcome.

Good results are obtained by using this method (Cristea et al., 2010) in the surgical treatment of tibial plateau fractures. This technique is adapted to resolve all tibial fractures type, not only Schatzker I - III, like some authors ( Siegler et al., 2011 ).

The advantages of this method are: minimal blood lost, small infection rate, good mobilization of the knee without pain, cheaper implants, reproductibility of the technique, it can be made in emergency, cost - efficient.

A single dose of antibiotics is admninistrated during surgery and anticoagulant for thrombembolism prophylaxis is done.

\section{References}

Asik M, Cetik O, Talu U, Sozen YV. Arthroscopy-assisted operative management of tibial plateau fractures. Knee Surg Sports Traumatol Arthrosc 2002;10:364-70.

Bobic V., O'Dwyer K. J. Tibial plateau fractures: the arthroscopic option Knee surg, sports Traumatol, Arthrosopy (1993) 1: 239-242

Buchko GM, Johnson DH: Arthroscopy assisted operative management of tibial plateau fractures, Clin Orthop 332:29, 1996;

Cassard X, Beaufils P, Blin JL, Hardy P. Osteosynthesis under athroscopic control of separated tibial plateau fractures. 26 case reports. Rev Chir Orthop 1999;85: 25766.

Casteleyn P.P., Handelberg F.: Fractures of the upper part of the tibia , Surgical Techniques in Orthopaedics and Traumatology, Elsevier, 55-510-A-10, 2001

Cristea St., Prundeanu A., Groseanu F., Atasiei T.: Minimal invasiv treatment of tibial plateau fractures Seventh SICOT/SIROT Annual International Conference on 31 August - 3 September 2010 in Gothenburg, Sweden poster 23768; 2010 
Cristea Şt., Prundeanu A., Groseanu F., Predescu V., Gârtonea D., Păpălici A., Olaru R.: Le rôle de l'arthroscopie dans le traitement percutané des fractures du plateau tibial Revue de Chirurgie Orthopédique Ms. Ref. No.: OTSR-RCO-D-11-00169 / 2011

Gill TJ, Moezzi DM, Oates KM, Sterett WI. Arthroscopic reduction and internal fixation of tibial plateau fractures in skiing. Clin Orthop Relat Res 2001;383:243 - 9.

Kayali C, Oztürk H, Altay T, Reisoglu A, Agus H. Arthroscopically assisted percutaneous osteosynthesis of lateral tibial plateau fractures. Can J Surg 2008;51:378-82.

Kenneth A.Egol and Kenneth J. Koval: Fractures in Adults Rockwood and Green's sixth edition Lippincott 2006 : vol 2 pag 1999 - 2029; 2006

Kiefer H, Zivaljevic N, Imbriglia JE Arthroscopic reduction and internal fixation (ARIF) of lateral tibial plateau fractures. Knee Surg Sports Traumatol Arthrosc. 2001 May;9(3):167-72.

Levy BA, Herrera DA, Macdonald P, Cole PA. The medial approach for arthroscopicassisted fixation of lateral tibial plateau fractures: patient selection and mid- to long-term results. J Orthop Trauma 2008;22:201-5.

Marsh JL, Smith ST, Do TT: External fixation and limioted internal fixation for complex fractures of tibial plateau, J Bone Joint Surg 77A:661,1995;

Mazoue CG, Guanche CA, Vrahas MS. Arthroscopic management of tibial plateau fractures: an unselected series. Am J Orthop 1999;28:508-15.

Mills WJ, Nork SE: Open reduction and internal fixation of high-energy tibial plateau fractures, Orthop Clin North Am 33:177,2002;

Morandi M, Pearse MF: Management of complex tibial plateau fractures with Ilizarov external fixator, Tech Orthop 11:125, 1996;

Pogliacomi F., Verdano M. A., Frattini M., Costantino C., Vaienti E., Soncini G.: Combined arthroscopic and radioscopic management of tibial plateau fractures: report of 18 clinical cases ACTA BIOMED 2005; 76; 107-114

Prundeanu A., Groseanu Fl., Gavrila M., Cristea St.: Treatment of tibial plateau fractures with minimal incision Archives of The Balkan Medical Union ISSN 0041 - 6940 VOL. VOL. 44, NO. 3, PP. 186-190, 2009

Rafii M, Lamont JG, Firooznia H: Tibial plateau fractures: CT evaluation and classification, Crit Rev Diagn Imaging 27:91,1987;

Roerdink WH, Oskam J, Vierhout PA. Arthroscopically assisted osteosynthesis of tibial plateau fractures in patients older than 55 years. Arthroscopy 2001;17:826-31.

Rossi R, Bonasia BE, Blonna D, Assom M, Castoldi F. Prospective follow-up of a simple arthroscopic-assisted technique for lateral tibial plateau fractures: results at 5 years. Knee 2008;15: 378-83.

Scheerlinck T, Ng CS, Handelberg F, Casteleyn PP. Medium-term results of percutaneous, arthroscopically-assisted osteosynthesis of fractures of the tibial plateau. J Bone Joint Surg Br 1998;80:959-64.

Siegler J., Galissier B., Marcheix P.S., Charissoux J.J., Mabit C., Arnaud J.P. : Osteosynthese percutanee sous arthroscopie des fractures des plateaux tibiaux: evaluation a moyen terme des resultats, Revue de chirurgie orthopedique et traumatologique , Vol.97, Nr 1, Fevr. 2011

Sirkin MS, Bono CM, Reilly MC, Behrens FF: Percutaneous methods of tibial plateau fixation, Clin Orthop 375:60, 2000; 
Tscherne H, Lobenhoffer P: Tibial plateau fractures: management and expected results, Clin Orthop 292:87,1993

Williams S., Hulstyn M., Fadale P., Lindy P., Ehrlich M., Coran J., Dorfman G. : Incidence of deep vein thrombosis after arthroscopic knee surgery, a prospective study, Arthroscopy, 1995, 11:701-705, 1995 


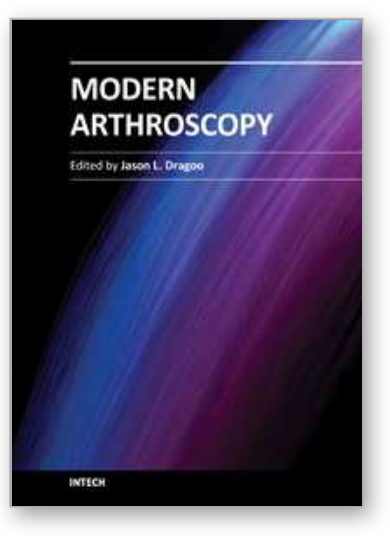

\author{
Modern Arthroscopy \\ Edited by Dr Jason L. Dragoo
}

ISBN 978-953-307-771-0

Hard cover, 302 pages

Publisher InTech

Published online 09, December, 2011

Published in print edition December, 2011

Modern Arthroscopy will assist practitioners to stay current in the rapidly changing field of arthroscopic surgery. The chapters in this book were written by a panel of international experts in the various disciplines of arthroscopy. The goals of this text are to present the classical techniques and teachings in the fields of Orthopaedics and Dentistry, but also to include new, cutting-edge applications of arthroscopy, such as temporomandibular arthroscopy and extra-articular arthroscopy of the knee, just to name a few. We hope Modern Arthroscopy becomes a core reference for your arthroscopic surgery practice.

\title{
How to reference
}

In order to correctly reference this scholarly work, feel free to copy and paste the following:

Şt. Cristea, A. Prundeanu, FI. Groseanu and D. Gârtonea (2011). The Role of Arthroscopy in Mini-Invasive Treatment of Tibial Plateau Fractures, Modern Arthroscopy, Dr Jason L. Dragoo (Ed.), ISBN: 978-953-307771-0, InTech, Available from: http://www.intechopen.com/books/modern-arthroscopy/the-role-of-arthroscopyin-mini-invasive-treatment-of-tibial-plateau-fractures

\section{INTECH}

open science | open minds

\section{InTech Europe}

University Campus STeP Ri

Slavka Krautzeka 83/A

51000 Rijeka, Croatia

Phone: +385 (51) 770447

Fax: +385 (51) 686166

www.intechopen.com

\section{InTech China}

Unit 405, Office Block, Hotel Equatorial Shanghai

No.65, Yan An Road (West), Shanghai, 200040, China

中国上海市延安西路65号上海国际贵都大饭店办公楼 405 单元

Phone: +86-21-62489820

Fax: $+86-21-62489821$ 
(C) 2011 The Author(s). Licensee IntechOpen. This is an open access article distributed under the terms of the Creative Commons Attribution 3.0 License, which permits unrestricted use, distribution, and reproduction in any medium, provided the original work is properly cited. 